\title{
The Impact of Regulatory Measures on the Development of Household Indebtedness
}

\author{
Jiř́ Rajl
}

\begin{abstract}
:
The purpose of this contribution is to evaluate the regulatory measures of the Czech central bank within the context of financial consumer protection aimed at slowing down the growth of the mortgage market by introducing new recommendations to restrict LTV limits and other indicators. Households are taking advantage of the availability of mortgage loans in an environment of economic growth and low unemployment. However, the growth in real estate prices raises fears of an increase in systemic risk caused by the developing gap between the growth of household indebtedness and the growth in real estate prices. The paper recapitulates the main factors of the growth rate of household indebtedness and the extent to which the adopted recommendations are effective.
\end{abstract}

Key words: Regulation of the credit market; Household debt; Credit bureau; Mortgage loan; Financial consumer protection; Creditworthiness.

JEL classification: E44, E58, G21.

\section{Introduction}

Since 2006, bank loans in the Czech Republic have been mostly composed of loans to households and their share is steadily increasing. Although it might be assumed that in a favourable economic situation, the level of indebtedness would fall, in fact, the positive development of GDP and wages has only impacted the reduction of the level of non-performing loans. In relation to the economic cycle, the development of indebtedness among the general population is, therefore, more procyclical in its character (Mandel, Teplý, 2018; Agénor, da Silva, 2017).

Moreover, the current development of the economic cycle, which looks favourable for consumers (showing high economic activity of the population combined with persisting demand for new workforce and strong growth of GDP by $4.7 \%$ in 2017; CSO, 2018), contributes to the declining proportion of non-performing loans.

Many studies focus on the impact of the growth of household indebtedness on disposable income and illustrate the financial sensitivity of households to external

\footnotetext{
Jiři Rajl; University of Economics, Prague, Faculty of Finance and Accounting, Department of Banking and Insurance, W. Churchill Sq. 4, 13067 Prague 3, Czech Republic, <rajj02@vse.cz>. The article is processed as an output of the research project Vývojové trendy v bankovnictví a pojištovnictví v podminkách ménícich se finančních trhü registered by the Grant Agency under the registration number VŠE IGA F1/21/2016.
} 
impacts. The rapid deterioration of the financial situation of households threatens the economy as a whole. The deterioration of the household financial situation in European countries is explained, for example, by the ECB's empirical analysis of the sustainability of household indebtedness (ECB, 2006).

Other studies point to the threat to the financial system due to low financial literacy, which affects especially low-income population groups (Gathergood, 2012; Cardaci, 2018). Another risk is the significant ratio of mortgage loans to total debt, which is associated with rising property prices and the related crises (Jorda et al., 2016).

In addition, the recent financial crisis has revealed the need to adjust the regulatory approach towards more targeted measures that can sufficiently respond to future fluctuations. Kabelík (2014, p. 53, 186) provides a detailed analysis of the regulatory changes that lead from Basel I to Basel III and argues that "the principal regulatory tool does need to be capable of identifying systemic risk". Based on his findings, there is a significant risk in the Czech banking sector which is connected to household indebtedness. "Balance sheets of Czech banks are exposed to a particularly large maturity mismatch relative to their western counterparts. In the light of the recent crisis this business model is considered safe but its stability should be treated with caution."

Heffernan (2014, p. 175) describes the systemic risk as a contagion which affects the whole financial system. "An extensive collapse will result in the loss of intermediation, money transmission and liquidity services offered by banks which, in turn, will cause an inefficient allocation of resources in the economy." She follows with a warning of the over-exposure in one area, such as mortgages, causing a potential property price collapse along with a rise in interest rates.

Furthermore, Debelle (2004, p. 51) emphasizes the problems associated with the impact of interest rate hikes "on the share of fixed versus variable rate mortgages held by households, with the sensitivity increasing more in those countries with predominantly variable rate mortgages". In the Czech Republic, mortgage loans with fixed interest rates prevail; however, a change of rates after the agreed time may cause a significant increase in the monthly instalments.

This leads to questions of whether households can be protected against overindebtedness and whether the regulation of the mortgage market is efficient enough. Moreover, there is also a question of whether borrowers can themselves evaluate their own financial situation. Unfortunately, households often assess the current favourable situation only from the short-term perspective and without sufficient regard to any future inability to pay off the increasing amounts of new mortgage loans which spiral upwards as mortgage availability falls. 


\section{Current Key Changes in Consumer Protection}

The competitive environment within the credit market of the Czech Republic is at a high level, not only from the point of view of banks, but also from the perspective of non-banking providers, who, to a certain extent, offer different products than banks, although part of the market is covered by both types of providers. Consumers can choose from a range of available credit products with varying prices, maturity dates, maximum amounts and other characteristics. Nevertheless, how is the consumer protected from over-indebtedness and moral hazard? With this aim in mind, the regulation - derived to a large extent from the European norms - harmonises the rules across the banking and non-banking sectors. One of the latest changes on the credit market has been the implementation of the so-called "mortgage directive" into the Czech legislation. The new law on consumer credit ${ }^{1}$ has brought a number of changes aimed at increasing the level of consumer protection.

The principal change was the transfer of control of the non-bank credit market to the Czech National Bank. This had an impact on the market in several areas. First and foremost, there was a significant reduction in the number of non-bank institutions allowed to offer consumer loans. In line with the above-mentioned law, the Czech National Bank initiated a licensing process which every non-bank provider had to undergo in order to be allowed to continue its activity following the deadline set at 31 May 2018. For companies with a larger market share and numerous clients, this licensing process did not represent a heavy burden, nor did it threaten their future operations on the financial market. Nevertheless, it was important to provide the documentation in various areas required by the regulator, ranging from the origin of capital to the details of the credit process. A significant factor for licence granting was the demonstration of a sufficient verification of the clients' creditworthiness when providing new financing. This licensing process led to the fall in the number of non-bank providers below one hundred, which, however, did not represent a significant redistribution of the "power". This is due to the fact that licences were granted not only to companies with a long tradition and a large market share, but also to companies operating locally with small numbers of clients and, in some cases unfortunately, with a dubious business model. The vast majority of agents and companies that ceased their activity were, in fact, hardly active at all and not even seeking the licence.

1 The Consumer Credit Act (no. 257/2016 Coll.) reflecting the requirements of the implementation of the principles of the directive of the European Parliament and Council 2014/17/EU of 4 February 2014 on consumer credit contracts for real estate designated for residential use and on changes to directive 2008/48/ES and 2013/36/EU and regulation (EU) no. 1093/2010. 
From the consumers' point of view, the licencing process has two aspects which have a direct impact on the availability of credit products. Firstly, consumers are able, on the regulator's website, to verify the granting of a licence to the subject from which they are requesting financing. Secondly, the granting of a licence is an indication of the sufficient verification of a company offering credit on the basis of the licence. This second aspect, however, may lead the consumers to assume that the granting of a licence to the consumer credit provider is in itself a sufficient protection against the practices which are harmful to the consumer. An example of this is the total cost of credit, which can vary greatly among individual providers and yet it is not sufficiently regulated. On the other hand, we should note that in this area a certain level of regulation has been adopted and there has been improvement from earlier practices.

Regulation by licensing thus differentiates between those providers who are authorised to operate on the market from unlicensed ones who provide loans illegally. The scope of the regulation depends on increased controls on the part of the regulator combined with adequate financial literacy of the consumers, who have to know how to defend themselves against illegally offered loans, either by reporting to the central bank or financial arbiter or, directly, by taking a legal action.

Furthermore, the new regulatory measures have not been effective against breaches of the established principles, and unfortunately, in some cases there has been no significant progress in controlling such companies that continue to violate the regulations; for example, encouraging consumers to request a new credit by acquiring the authorisation to conduct a commercial activity, and subsequently providing the new credit without the consumer protection.

For the central bank, the integration of supervision means not only more duties, but also more possibilities to monitor the development of the credit market as a whole; i.e., both from the perspective of the bank institutions and the non-bank providers of credit products alike. This integration increases the Czech National Bank's ability to protect the consumer.

\section{Regulatory Measures}

During the expansion phase of the economic cycle, risks start to appear, to which the regulator should respond in order to protect both the financial market and the consumers who use credit products. The uncontrollable growth of household indebtedness may, in the future, cause serious problems affecting several areas of the economy, which itself is a sufficient reason for the introduction of various measures aimed at preventing the deepening of crises during the periods of an economic decline. 
According to Revenda et al. (2014), the basic regulatory measures include influencing the amount of money in circulation or the price of money. Mandatory bank reserves at the central bank or selected short-term interest rates fulfil the role of the monetary policy operational criterion. By their regulation, central banks generally seek either to regulate the development of an intermediate criterion (e.g. monetary aggregates) or to directly influence the final monetary policy objectives. Monetary policy instruments can be structured based on several aspects depending on:

- the character - market or administrative instruments;

- the intensity of use - operational (permanent) or ad hoc instruments;

- the effectiveness - immediately applicable instruments or instruments providing a certain time for the banks to adapt;

- the impact on the banking system - instruments with the direct or indirect influence.

Since 2015, the Czech National Bank has been developing activities aimed at curbing the upward trend in household indebtedness. One of the most significant risks is the widening gap between real estate prices (the Czech National Bank's modelling approach suggests that at the end of 2017 the cost of housing was overvalued by about $14 \%$; CNB, 2018f) and the loans obtained to meet those prices. Since the central bank cannot use legal options to set regulatory measures, it regulates the mortgage market, besides the capital-based regulation ${ }^{2}$, in particular by issuing recommendations, which the banks generally follow. Some banks implemented the recommendations later or with a slight deviation. As these recommendations are not legally enforced regulations, it is not easy for the central bank to enforce systematically the behaviour it recommends. Modification of the Czech National Bank Act ${ }^{3}$ would allow the central bank to set rules which the banks would not be able to breach without violating the law. In light of the great respect in which the central bank is held by the commercial banks, such a power is superfluous. However, there is a real need for a law which would apply to entities operating in the Czech Republic on the basis of a European licence and are not directly subject to regulation in this area by the central bank. This would also apply to non-bank providers of credit products in order to ensure equal conditions on the financial market and to prevent unfair competition among credit providers (CNB, 2016b; CNB, 2018f).

When defining the so-called "risk management recommendations for the provision of retail loans secured by residential real estate", the central bank bases its definition on empirical monitoring of the development of indebtedness among the

\footnotetext{
$\mathrm{CNB}, 2018 \mathrm{f}$ provides the analysis of capital based regulatory measures.

The Czech National Bank Act (no. 6/1993 Coll.) as amended.
} 
general population in the field of mortgage loans. It is also fundamentally important to monitor the development of overall household debt arising from the use of products offered on both the banking and non-banking market.

The central bank issues recommendations (CNB, 2015; CNB, 2016a; CNB, $2017 \mathrm{~b}$; CNB, 2018b) within the framework of its monitoring of the targets of macroprudential policy and in connection with the recommendations of the European Systemic Risk Board (Recommendations of the ESRB on intermediate goals and mechanisms of macroprudential policy ESRB/2013), the recommendations of other international organs, and EU legislation (Financial Stability Board, 2012: FSB Principles for Sound Residential Mortgage Underwriting Practices; European Banking Authority, 2013: Opinion of the European Banking Authority on Good Practices for Responsible Mortgage Lending; directive 2014/17/EU).

The Czech National Bank's reaction to accelerating household debt has led to more intensive supervision of credit providers, especially in connection with the sustainability of the credit portfolio and its risk, as well as focussing on the credit standards used, which must be set according to the instructions of the European Banking Authority for the assessment of creditworthiness. Indeed, the Czech National Bank, in a supervisory statement on the credit provision to households, recommends that financial institutions use available bank and non-bank credit registers and other relevant databases so that the banks and financial institutions can sufficiently verify the creditworthiness of their clients and evaluate all the data relating to their debts (CNB, 2017a; EBA, 2015).

Household debt in the Czech Republic is accelerating especially due to mortgage loans because the banks are easing their credit standards while at the same time real estate prices are raising at an excessive rate. The recommendation of the central bank is a reaction to the increasing risk of a rapid deterioration in the quality of the credit portfolio in the future, which could occur if there is a downturn in the economic cycle.

Heffernan (2014, p. 162) refers to the high concentration of credit in one sector which may endanger the entire banking industry. The following is one of many examples of the over-exposure problem: "In Japan, the jusen ${ }^{4}$ or mortgage corporations collapsed in 1995 after over-exposure in the property markets, five years after they had been instructed by the regulators to curtail their lending to

4 Non-bank financial institutions in Japan that made mortgage loans. Jusen were created in the 1970s as subsidiaries of banks. Excessive lending by jusen in the 1980s contributed to Japan's real estate bubble. Several received bailouts in the 1990s but they nevertheless ceased operations in 1995 (Farlex Financial Dictionary, 2009). 
this sector - a directive they ignored at their peril, prompting a public outcry (public taxes were used to fund a government rescue)."

The banks, at least according to their own statements (CNB, 2018c; CNB, 2018d; $\mathrm{CNB}, 2018 \mathrm{e}$ ), have been tightening their credit standards in recent months. Nevertheless, the highly competitive environment prevents the use of more rigorous internal measures. The banks are raising their credit standards for mortgage loans in line with the regulator's recommendations, increasing costs of bank financing, and potential risks.

What aspects does the regulation by the central bank focus on? For a long time, the Czech National Bank has been striving to reduce the earlier identified systemic risk by restricting the volume of mortgage loans provided in relation to the value of mortgaged real estate (LTV - loan-to-value) and, more recently, in relation to the income of loan applicants (LTI - loan-to-income; LSTI - loan service-toincome; DTI - debt-to-income and DSTI - debt service-to-income), or other indicators. The Czech National Bank has set the aggregate (soft) limit and the individual (hard) limit, and if these limits are respected, there should be a reduction in mortgage loans provided. The hard limit is, by definition, not to be exceeded, while in the case of the soft limit, a specific percentage of the quarterly production is set, which may be exceeded following an individual assessment. When the limits were first introduced, the soft limit applied to $10 \%$ of the quarterly production. With effect from 1 April 2017 that figure was amended to $15 \%$.

The setting of limits in the first phase had no significant impact, so further amendments were implemented. The original hard limit set for LTV at $100 \%$ was gradually reduced to the current $90 \%$, while the soft limit was reduced from $90 \%$ to $80 \%$. Limits applying to the applicant's income were originally set at $40 \%$ of the applicant's monthly income for the total payment, and the total volume of the loan could amount to no more than eight times the applicant's annual income. In the end, the Czech National Bank eased these limits to $45 \%$ of the applicant's income and nine times his or her annual income with effect from 1 October 2018.

Lowering of the LTV limits may in turn paradoxically put the clients of the banks and financial institutions in a worse situation than if they had obtained a mortgage loan equal to $100 \%$ of the value of the real estate. When loans are combined this way, the total level of household debt is not reduced; there is simply a change in the structure of the product usage. Short-term loans or loans from building societies have a different character, and the costs in particular are significantly higher than in the case of mortgage loans. Moreover, when there is refixation of the interest rate affecting mortgage loans, it is unlikely that the new interest rates will reach the levels agreed for the short-term loans, and households which find it 
difficult to pay off their loans will incur greater costs. To avoid such a situation, it is therefore not enough to simply restrict the provision of mortgage loans; it is necessary to curb the overall dynamic of household debt and to monitor rigorously resources in the form of savings to avoid the use of a combination of several different loans from several different providers.

At first, the limits on LTV set earlier did not have much impact on the mortgage market as these affected an insignificant number of applicants who were already sufficiently restricted by the interest rate set by the banks themselves because of their higher level of risk. Nevertheless, the tightening of the limits will gradually contribute to a deceleration of the mortgage market. The long-term low average interest rate and the easing of credit standards therefore support the continual growth of indebtedness among the general population, which, in a period of the economic growth, does not cause any immediate problems. Nevertheless, in a period of the economic decline, it does represent increased risk, which the central bank is focussing on with its recommendations. The banks should therefore integrate further evaluation into the credit process to focus not only on the value of real estate, but also on the applicants' income. Moreover, that indicator should be subjected to stress testing.

In addition, the obligation to verify the income of mortgage applicants is not imposed on banks only as a recommendation from the central bank, but also by the above-mentioned new law on consumer credit, which imposes more demanding standards on credit providers when verifying borrowers' solvency. This law imposes on financial institutions the obligation to verify borrowers' income in order to prevent clients from becoming overindebted. Even if they have a positive credit history, an applicant may not obtain a mortgage simply because of their overall debt and the level of their monthly instalments, which they may not be able to cover from their monthly income. Through sufficient evaluation, the banks and financial institutions can prevent a situation in which a consumer later legally challenges the approval of a new loan by arguing that there was an insufficient evaluation of the applicant's later ability to settle the loan. In such a case, the financial institution is unable to collect the interest payments and charges, and the debtor may be legally absolved of those payments. The subsequent debt settlement is then bound only to the debtor's ability to pay off the loan, which in many cases means that the financial institution loses the loan completely.

The central bank announced (CNB, 2018f) that it had increased the microprudential supervision of banks to prevent circumvention of its recommendations. The combining of loans is not the only transgression against the central bank's recommendation to occur on the credit market. The Czech National Bank will also monitor adherence to a realistic method of evaluating mortgaged real estate to prevent the excessive overvaluation of real estate with the aim of 
proportionately increasing the volume of a mortgage. In order to prevent the combining of several mortgage loans, the Czech National Bank will monitor more indicators, which the banks must re-evaluate. Also in this case, the banks and financial institutions have a mechanism at their disposal which is able to effectively evaluate a combination of several loans from several providers. For a significant time, the banks and financial institutions have already been verifying their clients' data from the CIBR and the NBCIR by using credit reports from those registers to prevent the over-indebtedness. Consumers' credit reports present a client's overall debt as well as the level of his or her monthly debt burden. In addition, the Czech National Bank uses data from the registers to check the extent of combinations of various credit products from several financial institutions. Figure 1, which is based on data from the registers available to the Czech National Bank, shows the parallel growth of loans provided since the limits began to tighten.

\section{Fig. 1 Parallel provision of an unsecured loan and a mortgage}

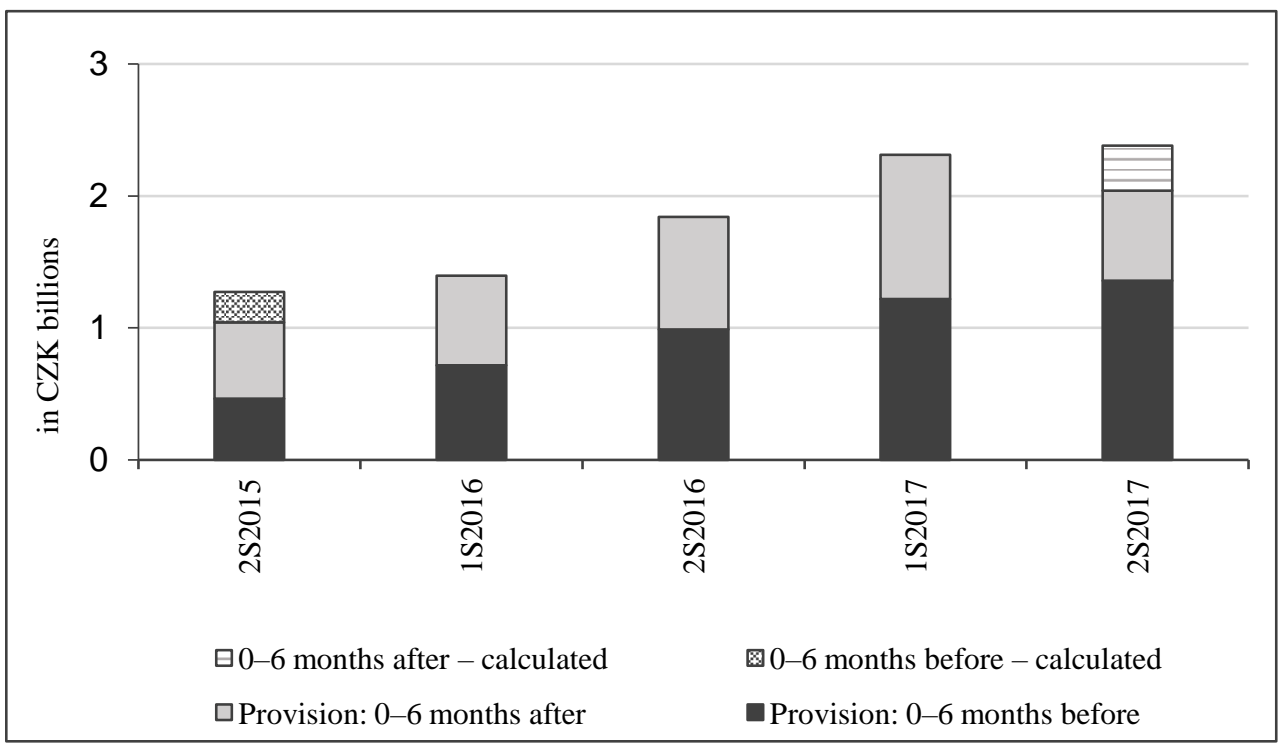

Source: The Czech National Bank (CNB, 2018a).

Note: The terms "before" and "after" relate to the time of provision of the mortgage. For the first and last period under review, the data are calculated for the whole period, as the known data do not cover the entire six months. The data for the time ranges of one year before and one year after the provision of the mortgage present a similar picture. 
Rajl, J.: The Impact of Regulatory Measures on the Development of Household Indebtedness.

\section{Development of Household Debt}

Growth in the household indebtedness increases as a result of the higher demand for mortgage loans. However, from the perspective of a relative expression, there is no significant fluctuation, as the growth is accompanied by a relatively strong growth in household earnings. Much higher rate of the household indebtedness relative to GDP, net disposable income and primary household income was recorded between 2000 and 2010, according to the analysis of Mandel, Teplý (2018). Equally on the basis of another analysis of Frait (2018), the relative indebtedness of Czech households has grown from a 50\% share of the gross disposable income to almost $60 \%$ over the last 8 years.

\section{Fig. 2 Development of household debt}

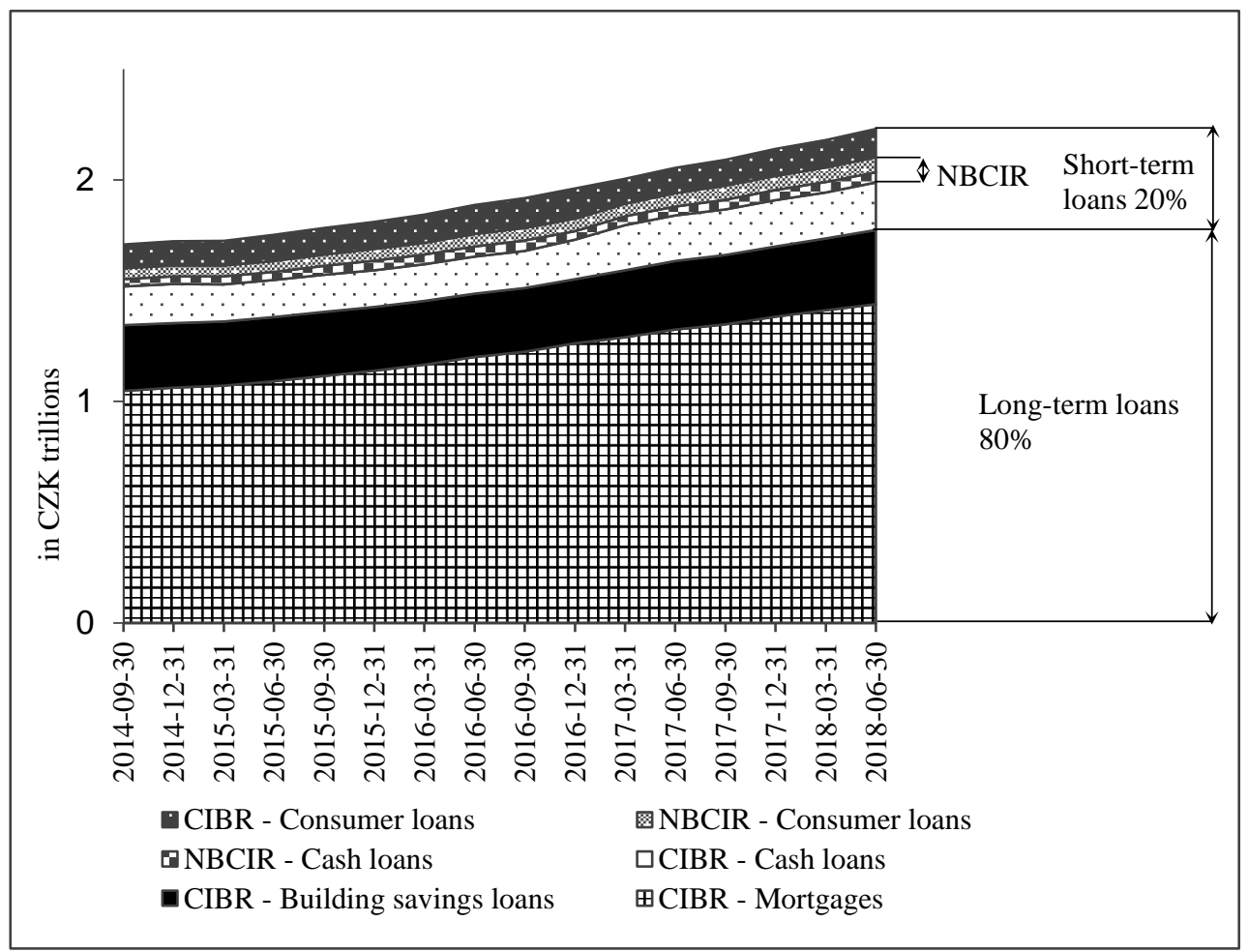

Source: Based on data from the Client Information Bank Register (CBCB, 2018) and the Non-Bank Client Information Register (CNCB, 2018).

Note: Long-term loans - mortgage loans, building savings loans; Short-term loans financial leasing, operational leasing, personal non-targeted loans, purposive loans, sale in instalments including hire-purchase, credit cards, revolving credit, investment loans, operational loans, overdraft/authorized or unauthorized debit on a current account etc. 
Figure 2 splits the current overall household debt into the individual groups of loans as well as distinguishes between the obligations to the bank market and the non-banking market on the basis of data from the credit registers.

Loans to cover housing represent $80 \%$ of all loans provided, and their share of the overall indebtedness among the population is constantly increasing. Household debt in the case of the non-bank providers represents only a smaller part compared to the bank loans. Nevertheless, the above-mentioned combination of various loans, their due dates, and their varying total costs may in the future contribute to significant problems with the settlement of loans.

Non-banking financial institutions provide more purposive consumer loans used by households to purchase, in particular, cars and household goods. Banks, on the other hand, provide in the case of short-terms loans more non-purposive cash loans.

The average number of contracts per borrower with a long-term loan is 1.2 and for those with short-term loans it is 1.8 . Without differentiating among the types of loan, the registers record an average of 1.9 contracts per borrower. This ratio has hardly changed in recent years. There has been only a slight increase in the average number of contracts with long-term loans per client and a decrease in the number of short-term loan contracts per client.

In total, therefore, there has been more of a reduction in the number of contracts between clients and banks or other financial institutions, and their ratio is shifting in favour of the longer-term loans. This means that the gradual reduction of the mortgage market has a partial impact on the number of new loans, but it does not have a significant effect on their amount, as new loans are of a higher value.

The number of debtors is not growing, but the average amount of money borrowed is on the rise. Active debt, as recorded in the credit register, is being paid off by more than 3 million people, and that figure has been stable for a long time. Indeed, household debt is constantly attaining new maximums, but this is not caused by a greater number of debtors.

Since approximately the start of 2016 when the tendency of the regulator to restrict the pace of growth of mortgage loans was announced, there has been a gradual decline in the number of clients with a mortgage; while the number of clients with short-term loans has increased. Moreover, since the third quarter of 2017, there has been an increase in the number of clients with both a short-term and long-term debt, which indicates a higher proportion of the combinations of a short-term and long-term debt by households. 


\section{Fig. 3 New long-term and short-term loans}

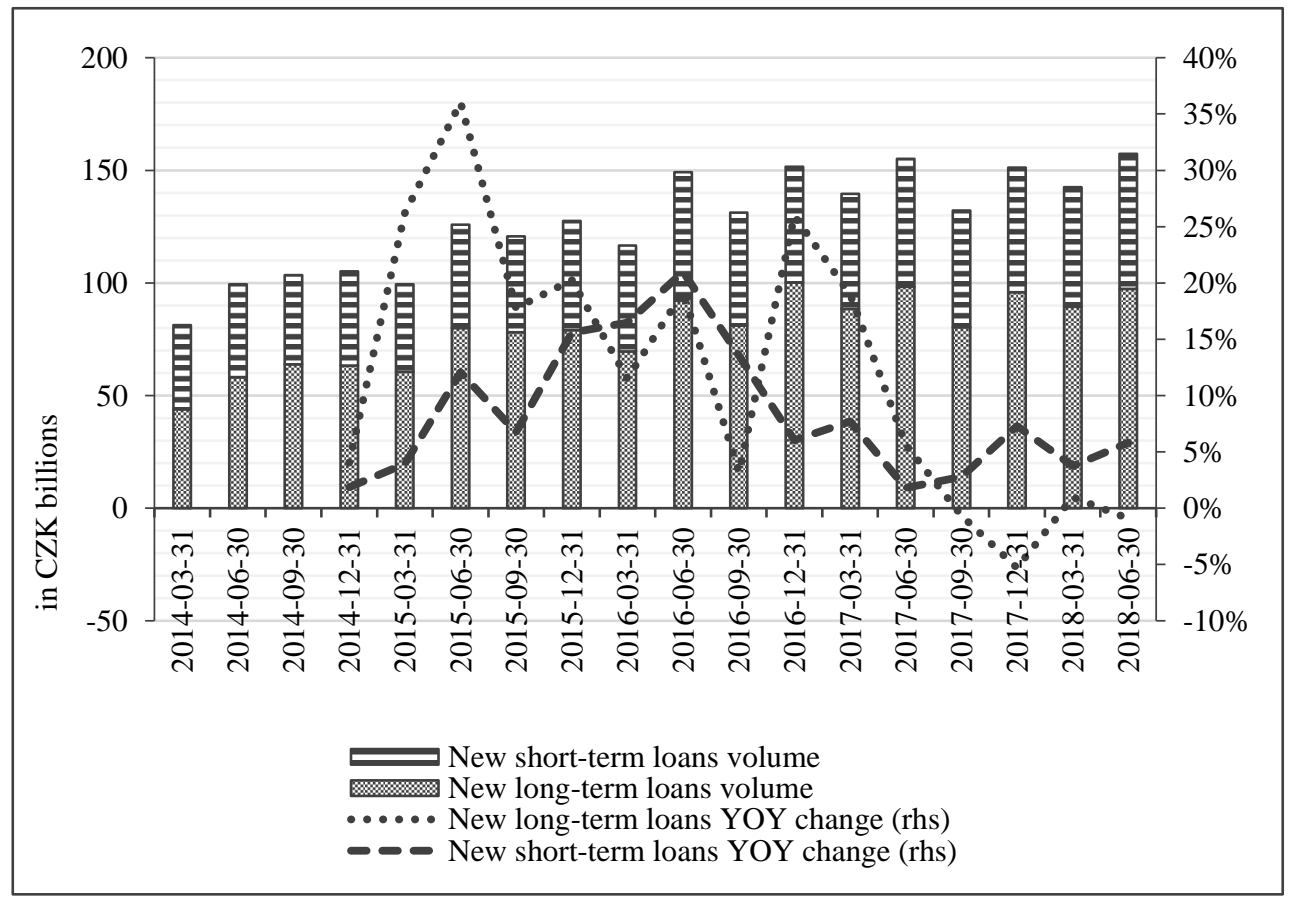

Source: Based on data from the Client Information Bank Register (CBCB, 2018) and the Non-Bank Client Information Register (CNCB, 2018).

The total volume of new mortgage loans and loans from building societies in the first half of 2018 basically reaches the same values as those for the same period of the previous year. As interest rates rise, we may assume that the growth in household debt due to mortgage loans will gradually decline, and the volume of new loans in 2018 will probably not exceed the value recorded in 2017. Nevertheless, there will not be a significant deviation from the trend. In that respect, 2017 was a record year, and from this year onwards we may expect a certain cooling down in the rate of growth in household debt, which is shown in Figure 3 by the year-on-year growth rate, which has been declining for the last few quarters.

In addition, the rate for the long-term loans is declining faster than that for the short-term loans. This figure displays a certain seasonal variation, which occurs on the credit market. However, it is not strong enough to have a significant impact on the overall trend. Moreover, the same applies for refinancing of mortgage loans, as the ratio of such loans to new mortgage loans is from the perspective of a longer period of time between $10 \%$ and $20 \%$ (Frait, 2018). 
As mentioned above, one of the factors which have a large impact on the demand for mortgages is the low rate of interest. The development of the average rate for mortgage loans, as shown in Figure 4, indicates previously favourable conditions for those applying for new mortgage loans. The average interest rate declined for a long time until the end of 2016, when it began to rise again. Additionally, the current rapid growth of the $2 \mathrm{~W}$ repo rate will contribute to the further, faster growth of interest rates, thereby slowing the pace of new debt.

\section{Fig. 4 Average interest rate on mortgage loans and $2 \mathrm{~W}$ repo rate}

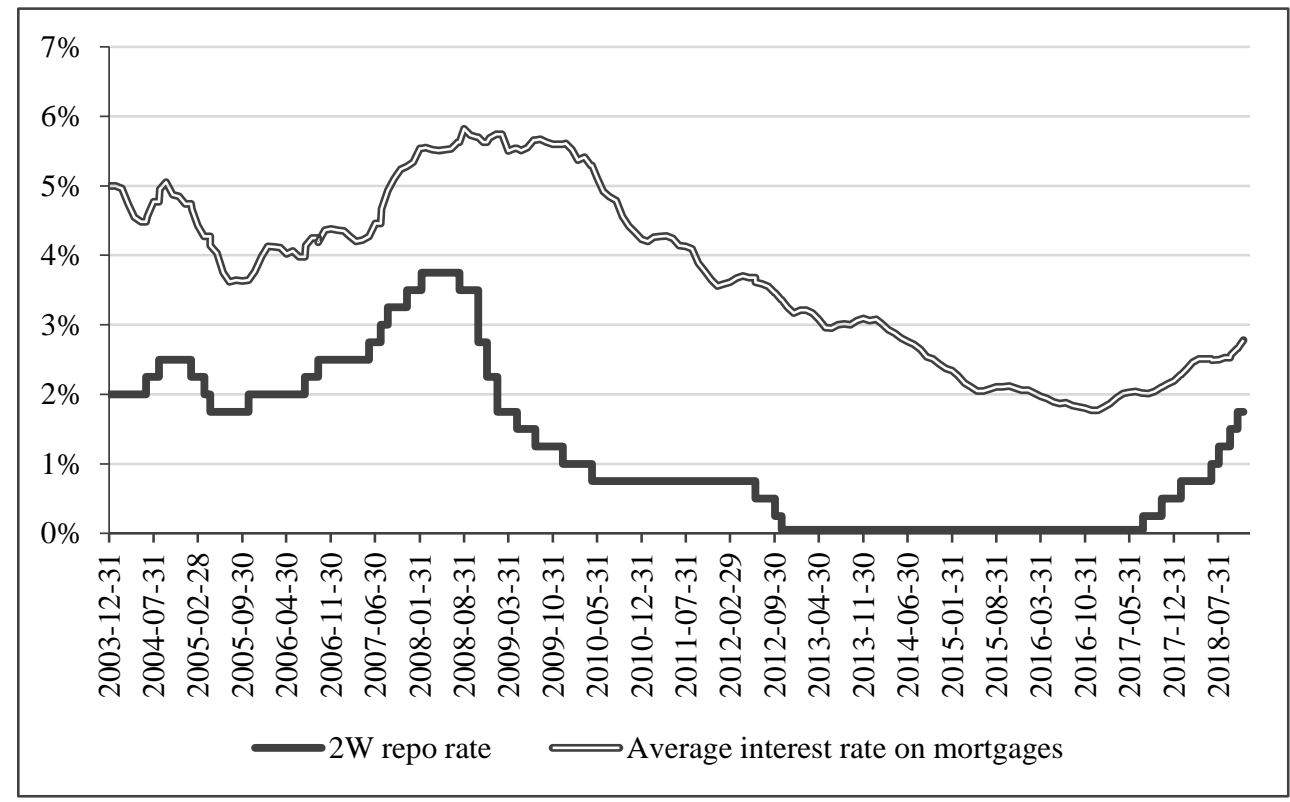

Source: Based on data from the Czech National Bank (CNB, 2018a) and the Fincentrum Hypoindex (2018).

In the case of the long-term loans, the current situation in the market clearly displays the effort made by the clients of banks to make use of the described advantageous conditions for new mortgage loans for housing before significant restrictions come into effect. The average interest rate has been rising since the beginning of 2017 despite strong competition among banks, which, for their part, are striving to take advantage of the situation where there is a strong demand for mortgage loans. The regulator's attempt to curb the rate of indebtedness has basically driven a larger proportion of the clients to apply for a mortgage loan in the shortest time possible before the conditions become significantly disadvantageous for them. On the other hand, it is apparent that this type of behaviour does not apply to the whole portfolio of the bank clients and that it will not be a longer-term change. 
As we have already stated, the long-term loans among the general population comprise $80 \%$ of the total debt. However, non-payment in this debt category threatens a smaller volume of money than in the case of the short-term debt. In the case of debt per client, the reverse applies as borrowers who find it difficult to fulfil their obligations on average fail to pay off a larger volume of the long-term debt than the short-term debt. In addition, this indicator is gradually rising. The number of people recorded as not fulfilling obligations is falling, but their average level of threatened debt is rising.

\section{Fig. 5 Share of non-performing loans}

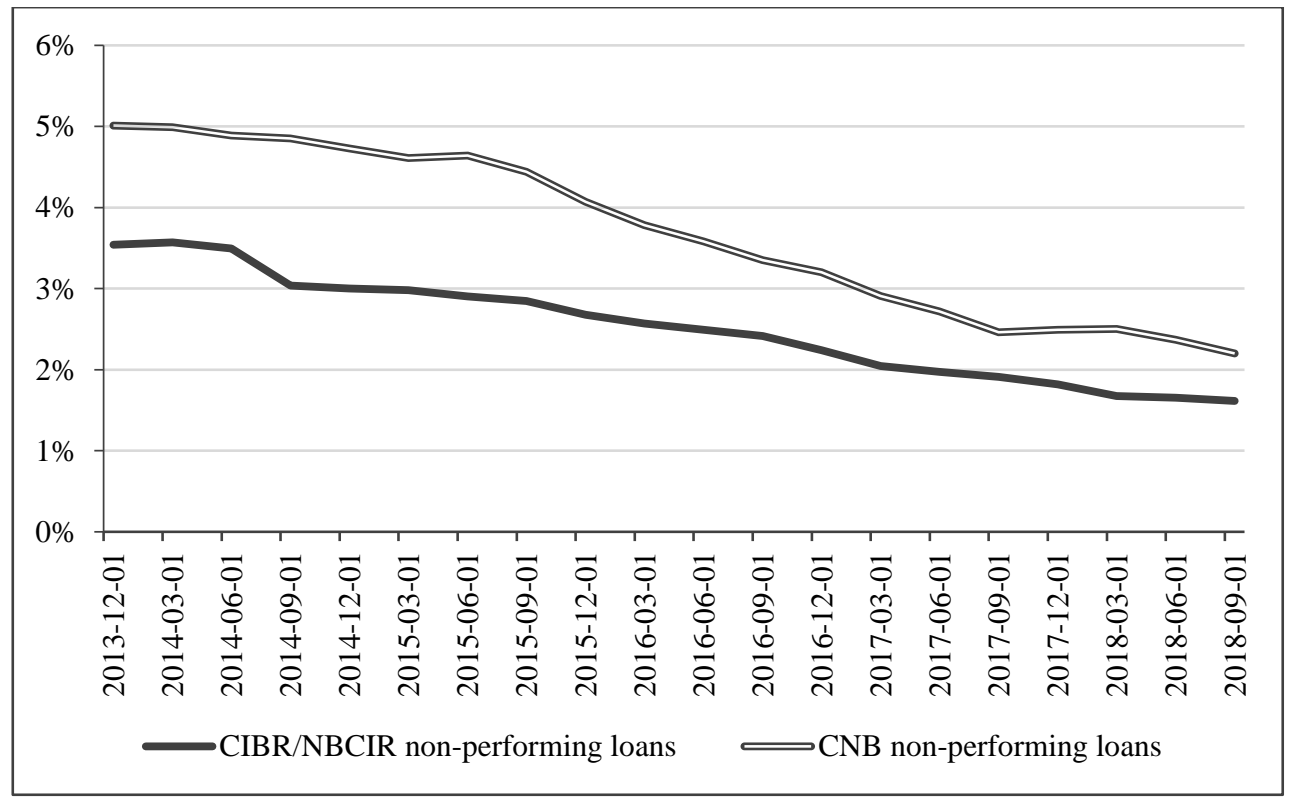

Source: Based on data from the Client Information Bank Register (CBCB, 2018), the NonBank Client Information Register (CNCB, 2018) and the Czech National Bank (CNB, 2018a).

Note: The statistics of the central bank considers data from the reference banks. The curve of non-performing loans recorded in the Client Information Bank Register and the NonBank Client Information Register (CIBR and NBCIR) is calculated from the data of the users of these registers, i.e. banks in the case of the CIBR and non-banking financial institutions in the case of the NBCIR. The reporting base and the method of calculation of the two sources differ. Nevertheless, the trends depict an analogous picture of the ability of households to pay off their obligations, whose volume is, in addition, increasing steadily.

The registers record the highest average threatened volume of the long-term debt among the youngest group of borrowers, i.e. those aged between 15 and 24. In the case of the short-term debt, the highest average is among people aged 45 to 54 . The highest volume of threatened debt was recorded by the registers at the end of 
the first half of 2018 in the 35 to 44 age group. This group, however, has also the highest level of indebtedness; therefore, borrowers in this group are not on average among those with significant problems paying-off their debt.

Growth in the relative household indebtedness and the debt structure may result in a significant fall in the disposable income when facing a rise of interest rates. Higher payments of mortgage loans are potentially threatening especially for the youngest and oldest age groups of the population. Frait (2014) shows the rise in the median instalment for mortgage loans by up to $40 \%$, with rates rising by 3.5 percentage points.

\section{Conclusion}

If we compare the effectiveness of the various regulatory recommendations, the average interest rate for mortgage loans and the raising of the central bank's basic two-week repo rate, it is clear that, approximately since the start of 2017, there has been a conjunction of several factors which can have a positive impact by easing the pace of the increase in household debt. The cost of mortgages is gradually rising, and the level of LTV and other indicators is being restricted, which increases the requirement for co-financing on the part of the borrower. Increases in the repo rate will have a further impact on the rise of interest rates affecting mortgage loans and the rise of deposit rates, which, on conservative markets such as the financial market in the Czech Republic, will create conditions for increasing savings. Individual factors do not, however, have an immediate effect, and the final impact on the inhibition of the mortgage market is gradual and slow.

Non-bank providers of consumer credit focus more on the short-term loans, or loans which are secured by real estate, but do not have the character of traditional mortgages. Banks have a $95 \%$ market share, while only $5 \%$ of the debt is accounted for by non-bank providers. This situation could change in the long-term if there is an attempt to restrict the pace of household debt arising from mortgage loans, which will experience a gradual deceleration, and, due to the new requirements on savings for mortgage applicants, households seek ways of replacing savings with short-term loans. The regulator, however, regards such practices as undesirable and monitors the overall household debt. Banks should not support mortgage loans with further loans, although this does happen in some cases.

As we displayed, one of the main tasks for the Czech National Bank, from its macroprudential viewpoint, is to protect the market from growing systemic risk. However, the absence of sufficient legal support for that effort causes certain restrictions, which may weaken the regulation. This is another reason why panEuropean regulation, which allows for the establishment of similar conditions on 
the European market, is a positive factor. To maintain equal regulatory conditions, it is of benefit to view the EU member states as a whole, and for that reason the ESRB recommends the mutual recognition of individual recommendations on the basis of reciprocity in international comparisons. Macroprudential policy de facto assumes that individual measures have an impact on multinational financial conglomerates and holdings operating in several countries either directly or via subsidiaries. The recognition of individual measures is not automatic and it is subject to approval in the countries in which the measures are expected to be implemented. In the case of significant interventions, there may be regulatory arbitrage, which disrupts the EU's internal market and weakens macroprudential policy in the various member states. The systematic evaluation of these crossborder effects in the Czech environment is not of great importance, as financial institutions operate on the local financial market predominantly directly and are subject to the regulatory measures of the central bank. There are only a few subsidiaries of foreign banks and their exposure is insignificant. (CNB, 2017b; ESRB, 2015; ESRB, 2017).

The paper provided a description of applied regulatory measures in the Czech financial market and assessed their efficiency. Despite the measures implemented, the growth in household debt is not decelerating, and households are making greater use of the possibility of relatively easily obtained mortgage loans. A partial restriction is introduced by the extension of the regulatory measures in combination with a restriction of LTV limits and, at the same time, the necessity to verify rigorously the indicators of DSTI and DTI. A restriction will contribute to greater competitiveness, especially in the drive to gain middle-aged clients, who have relatively greater savings and who are easier for banks to provide loans to. The question remains: how will behave those households which are unable to obtain a loan and do not have sufficient savings?

\section{References}

Agénor, P. R., da Silva, L. P., 2017. Cyclically adjusted provisions and financial stability. Journal of Financial Stability 28, 143-162. DOI: 10.1016/j.jfs.2016.12.009.

Cardaci, A., 2018. Inequality, household debt and financial instability: An agentbased perspective. Journal of economic behaviour \& organization 149, 434-458. DOI: 10.1016/j.jebo.2018.01.010.

Czech Banking Credit Bureau (CBCB), 2018. Credit market barometer. Available from: <cbcb.cz/uverovy-barometr>. [28 December 2018]. 
Czech National Bank (CNB), 2015. Recommendation on the management of risks associated with the provision of retail loans secured by residential property. Available from: <cnb.cz/export/sites/cnb/cs/legislativa/.galleries/VestnikCNB/2015/vestnik_2015_06_20615180.pdf>. [7 May 2019].

Czech National Bank (CNB), 2016a. Recommendation on the management of risks associated with the provision of retail loans secured by residential property. Available from: <cnb.cz/export/sites/cnb/cs/legislativa/.galleries/VestnikCNB/2016/vestnik_2016_06_20616180.pdf>. [7 May 2019].

Czech National Bank (CNB), 2016b. Financial stability report 2016/2017. Available from: <cnb.cz/export/sites/cnb/cs/financnistabilita/.galleries/zpravy_fs/fs_2016-2017/fs_2016-2017.pdf>. [7 May 2019].

Czech National Bank (CNB), 2017a. Supervisory statement no.1/2017 on the provision of loans to households by lending institutions. Available from: <cnb.cz/export/sites/cnb/cs/dohled-financnitrh/.galleries/vykon_dohledu/dohledove_benchmarky/download/dohledove_sdelen i_2017_01.pdf>. [7 May 2019].

Czech National Bank (CNB), 2017b. Recommendation on the management of risks associated with the provision of retail loans secured by residential property. Available from: <cnb.cz/export/sites/cnb/cs/legislativa/.galleries/VestnikCNB/2017/vestnik_2017_07_20717180.pdf>. [7 May 2019].

Czech National Bank (CNB), 2018a. ARAD time series database. Available from: <cnb.cz/docs/ARADY/HTML/index.htm>. [28 December 2018].

Czech National Bank (CNB), 2018b. Recommendation on the management of risks associated with the provision of retail loans secured by residential property. Available from: <cnb.cz/export/sites/cnb/cs/legislativa/.galleries/VestnikCNB/2018/vestnik_2018_08_21018180.pdf>. [7 May 2019].

Czech National Bank (CNB), 2018c. Bank lending survey - January. Available from: <cnb.cz/export/sites/cnb/cs/financni-stabilita/setreni-uverovych-podminekbank/.galleries/uverove_setreni/2017_q4_BLS.pdf>. [7 May 2019].

Czech National Bank (CNB), 2018d. Bank lending survey - April. Available from: <cnb.cz/export/sites/cnb/cs/financni-stabilita/setreni-uverovych-podminekbank/.galleries/uverove_setreni/2018_q1_BLS.pdf>. [7 May 2019].

Czech National Bank (CNB), 2018e. Bank lending survey - July. Available from: $<\mathrm{cnb}$.cz/export/sites/cnb/cs/financni-stabilita/setreni-uverovych-podminekbank/.galleries/uverove_setreni/2018_q2_BLS.pdf>. [7 May 2019]. 
Czech National Bank (CNB), 2018f. Financial stability report 2017/2018. Available from: $<$ cnb.cz/export/sites/cnb/cs/financnistabilita/.galleries/zpravy_fs/fs_2017-2018/fs_2017-2018.pdf>. [7 May 2019].

Czech Non-Banking Credit Bureau (CNCB), 2018. Credit market barometer. Available from: <cncb.cz/uverovy-barometr>. [28 December 2018].

Czech Statistical Office (CSO), 2018. Statistics. Available from: <czso.cz/csu/czso/statistiky>. [19 December 2018].

Debelle, Guy, 2004. Household debt and the macroeconomy. BIS Quarterly Review. Available from: <bis.org/publ/qtrpdf/r_qt0403e.htm>. [28 December 2018].

European Banking Authority (EBA), 2015. General guidelines of the European Banking Authority. Available from: <eba.europa.eu/documents/10180/1162894/EBA-GL-2015-

11_CS_+GL+on+creditworthiness.pdf/8d5d0108-f433-403f-b486-b3ff0047486b>. [7 May 2019].

European Central Bank (ECB), 2006. Household debt sustainability. What explains household non-performing loans? An empirical analysis. Working paper series, no. 570, January 2006. Available from: <ecb.europa.eu/pub/pdf/scpwps/ecbwp570.pdf>. [7 May 2019].

European Systemic Risk Board (ESRB), 2015. Recommendation of the European Systemic Risk Board of 15 December 2015 on the assessment of cross-border effects of and voluntary reciprocity for macroprudential policy measures. Available from: <esrb.europa.eu/pub/pdf/recommendations/2015/ESRB_2015_2.c s.pdf>. [7 May 2019].

European Systemic Risk Board (ESRB), 2017. Recommendation of the European Systemic Risk Board of 20 October 2017 amending recommendation ESRB/2015/2 on the assessment of cross-border effects of and voluntary reciprocity for macroprudential policy measures. Available from: <esrb.europa.eu/pub/pdf/recommendations/2017/ESRB_2017_4.cs.pdf?afd553a80 e26e06d9b8453aa9b3d72e0>. [7 May 2019].

Farlex Financial Dictionary, 2009. Jusen. Available from: <financialdictionary.thefreedictionary.com/Jusen>. [27 December 2018].

Fincentrum Hypoindex, 2018. Fincentrum Hypoindex. Available from: <hypoindex.cz/hypoindex-vyvoj>. [28 December 2018]. 
Frait, J., 2018. Doporučení ČNB pro poskytování hypotečních úvěrů - reakce a dosavadní realita. Available from: <docplayer.cz/110572161-Doporuceni-cnb-proposkytovani-hypotecnich-uveru-reakce-a-dosavadni-realita.html> . [7 May 2019].

Gathergood, J., 2012. Self-control, financial literacy and consumer overindebtedness. Journal of economic psychology, vol. 33, no. 3, 590-602. DOI: 10.1016/j.joep.2011.11.006.

Heffernan, S., 2014. Modern Banking. John Wiley \& Sons Ltd., Chichester.

Jorda, O., Schularick, M., Taylor, A. M., 2016. The great mortgaging: housing finance, crises and business cycles. Economic policy, vol. 31, no. 85, 107-152. DOI: 10.1093/epolic/eiv017.

Kabelík, K., 2014. Banking Regulation. Trends \& Impacts. Czech Banking Association, Prague.

Mandel, M., Teplý, P., 2018. Finanční chování domácností v ČR v teorii a praxi (The financial behaviour of households in the Czech Republic in theory and practice). Available from: <czech-ba.cz/sites/default/files/studie_cba_final.pdf>. [13 January 2019].

Revenda, Z., Mandel, M., Kodera, J., Musílek, P., Dvořák, P., 2014. Peněžní ekonomie a bankovnictví. Management Press, Prague. 
